\title{
HISTÓRIAS DE MULHERES MILITANTES NA PERSPECTIVA DOS(AS) FILHOS(AS): (DES)ENGAJAMENTOS POLIITICOS
}

\author{
JAIME SANTOS JUNIOR ${ }^{1}$ \\ Marilda Aparecida de Menezes²
}

\begin{abstract}
RESUMO: A partir das narrativas biográficas de duas mulheres, ex-metalúrgicas e com militância no Sindicato dos Metalúrgicos do ABC (SMABC) entre as décadas de 1970 e 1990, este artigo analisa o processo de transmissão e aprendizado dessas memórias no interior das famílias, a fim de compreender não apenas sua perenidade, mas, sobretudo, a maneira como elas são recebidas pelas novas gerações. A pesquisa foi feita entre os anos de 2017 e 2020, no âmbito de um projeto que analisou as memórias das greves históricas de canavieiros e metalúrgicos no fim da década de 1970. Os resultados sugerem que o contraste entre conjunturas muito diferentes e a reinterpretação dessas memórias evidenciam as fraturas nos modos de apropriação e engajamento político pelas novas gerações.
\end{abstract}

Palavras-chave: Memórias. Sindicalismo. Geração. Educação política. ABC Paulista.

\section{STORIES OF MILITANT WOMEN FROM THE PERSPECTIVE OF THEIR CHILDREN: (DIS) POLITICAL ENGAGEMENTS}

\begin{abstract}
Based on biographical narratives of two women, former metallurgists and active members of the ABC Metalworkers Union (SMABC, in Portuguese) between the 1970s and 1990s, this paper aims to analyze the transmission and learning process of these memories within families in order to understand not only their continuity, but, above all, the way that they are received by new generations. The results suggest that the contrast between different social contexts and the reinterpretation of these memories show the fractures in the modes of appropriation and political engagement by new generations.
\end{abstract}

Keywords: Memories. Unionism. Generation. Political education. ABC Paulista.

Este artigo trata-se do projeto Movimentos Cruzados e Histórias Específicas de Operários e Trabalhadores Rurais. Análise Comparativa dos Ciclos de Greves Iniciados pelos Metalúrgicos de São Paulo e do ABC Paulista e pelos Canavieiros de Pernambuco no Final dos Anos 70. O projeto teve financiamento da CAPES, edital n. 12/2015, e foi coordenado pelo Prof. Dr. José Sérgio Leite Lopes (UFRJ/Museu Nacional).

1.Universidade Federal do Paraná - Departamento de Sociologia - Programa de Pós-graduação em Sociologia - Curitiba (PR), Brasil. E-mail: jaimesjr@ufpr.br

2.Universidade Federal do ABC - Programa de Pós-graduação em Ciências Humanas e Sociais - Santo André (SP), Brasil/Universidade Estadual de Campinas - Programa de Pós-graduação em Ciências Sociais - Campinas (SP), Brasil. E-mail: menezesmarilda@gmail.com

Editor de Seção: Adriana Dragone Silveira 


\title{
HISTORIAS DE MUJERES MILITANTES DESDE LA PERSPECTIVA DE SUS HIJOS(AS): (DES)COMPROMISOS POLÍTICOS
}

\begin{abstract}
RESUMEN: Basado en las narraciones biográficas de dos mujeres, ex metalúrgicas y miembros activos de Sindicato Metalurgico del ABC Paulista (SMABC) entre las décadas de 1970 y 1990, este artículo analiza el proceso de transmisión y aprendizaje de estos recuerdos dentro de las familias a fin de comprender no solo su continuidad, sino, sobre todo, la forma en que las reciben las nuevas generaciones. La investigación se llevó a cabo entre los años 2017 y 2020, como parte de un proyecto que analizó los recuerdos de las huelgas históricas de la caña de azúcar y los metalúrgicos a fines de la década de 1970. Los resultados sugieren que el contraste entre circunstancias muy diferentes y la reinterpretación de estos recuerdos muestran las fracturas en los modos de apropiación y compromiso político de las nuevas generaciones.
\end{abstract}

Palabras-clave: Memorias. Sindicatos. Generación. Educación política. ABC Paulista.

\section{Memórias em Diálogo}

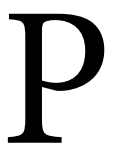

assados quarenta anos das greves históricas promovidas pelos metalúrgicos do ABC Paulista, ocorridas entre o fim da década de 1970 e o início da de 1980, estávamos no Sindicato dos Metalúrgicos do $\mathrm{ABC}(\mathrm{SMABC})$ para levar à frente um projeto de pesquisa que se propunha analisar comparativamente as greves de metalúrgicos de São Paulo, do ABC Paulista e de trabalhadores rurais canavieiros em Pernambuco, as quais ocorreram no período citado ${ }^{1}$. O objetivo principal era menos o de recontar as histórias desses grandes movimentos, no desejo por inserir fatos novos às histórias, e mais o de analisar as memórias de antigos militantes, homens e mulheres, que participaram daqueles acontecimentos. O substrato seria, então, composto pelas narrativas, por meio das quais almejávamos acessar as trajetórias ocupacionais dos militantes - os engajamentos políticos, o cotidiano do trabalho, as práticas sindicais, apenas para citar os aspectos mais candentes -, como forma de unir, para comparar, dois grandes acontecimentos históricos tomados separadamente pela literatura que se adensou em torno deles - reflexo, talvez, das cisões entre uma história do trabalho e do sindicalismo urbano e industrial e outra, rural.

Ainda nessa ocasião, seguimos as pistas deixadas por Souza-Lobo (2011) e Humphrey (1983), os quais já haviam exposto as tensões de uma classe trabalhadora que se apresentava no masculino, muitas vezes subsumindo a atuação das mulheres. No registro das memórias que colhemos, o silenciamento dessas mulheres trabalhadoras ainda reverberava no tempo presente, mesmo passados quarenta anos, quando atores disputavam, no mercado das narrativas, a legitimidade das suas histórias. Contudo, se, de algum modo, é correto dizer que tropeçamos com esse achado quando, no registro etnográfico, percebemos a aparente recusa das mulheres ex-militantes de participares da pesquisa, sempre com o argumento de que suas histórias "não eram importantes", recuperávamos um argumento já esboçado em pesquisa que fizemos com famílias de migrantes nordestinos, ex-metalúrgicos, no ABC Paulista (SANTOS JUNIOR; THIBES; MENEZES, 2019): o de que o legado dessas trajetórias familiares, que se transmutava como expectativa dos pais em relação aos filhos, no que tange a educação, a inserção profissional, os valores etc., constituía elementos de intensa negociação e expunha as fissuras do que poderia ser visto como continuidade ou ruptura das solidariedades tecidas no espaço das famílias. 
Havia, portanto, bons indícios para seguirmos trabalhando com a hipótese de que os processos de transmissão e aprendizado dessas memórias, na relação geracional, permitir-nos-ia compreender não apenas a perenidade das memórias, mas, sobretudo, a maneira como elas eram recebidas pelas novas gerações, uma vez que a efervescência do registro das memórias de trabalhadores e trabalhadoras, bem como dos lugares de memória do trabalho - como dão prova as autobiografias, as associações que celebram culturas de ofício, a construção de museus dedicados ao tema do trabalho -, colocam em evidência os usos e apropriações da memória. No atual contexto, não seria arriscado dizer que essa valorização da memória ocorre em contraposição ao envelhecimento do "valor trabalho" (MÉDA, 2010) ou, para dizer de outro modo, da "pessoa memória" em lugar da "pessoa trabalho". Todavia, isso não vaticina um cenário. Em vez disso, sugere tensões e conflitos presentes nas formas de apresentação das "narrativas de si" (RICOEUR, 1991) e a recepção, por outros, das experiências de trabalho e engajamentos sócio-políticos. Aqui, radica-se o objetivo deste artigo, que pretende analisar os processos de transmissão geracional das memórias de duas ex-militantes sindicais metalúrgicas do ABC Paulista por meio dos relatos de seus filhos e filhas.

Os casos foram selecionados em razão da forte atuação como militantes sindicais, destoando, com isso, das demais trajetórias que analisamos em razão da já sabida baixa participação das mulheres nas estruturas sindicais naquele período ${ }^{2}$. Entretanto, elas permanecem, ainda que em graus variados, ligadas ao SMABC ou à Associação de Metalúrgicos Anistiados e Anistiandos do ABC (AMA-A ABC) - o que nos permite realçar uma forma de engajamento político que ocorre no tempo presente, elemento que será tensionado na família e nas trajetórias. A despeito do corte geracional, a nossa unidade de análise será a família, pois julgamos que é nela que incidem as dinâmicas de transmissão, aprendizado e negociação do legado dos pais. São memórias que não se referem meramente a um tempo passado: nosso alvo é o modo como elas são apreendidas atualmente. Contar é, a um só tempo, avivar, reunir e apresentar, e, portanto, editar, o conteúdo do que foi vivido, como sugere Halbwachs (2013). Estamos operando na chave que reconhece a reflexividade do ato de narrar para dirimir o risco outrora aventado por Bourdieu (2006).

A continuidade da pesquisa para incorporar os membros da segunda geração ocorreu em meio às restrições impostas pela pandemia de Covid-19, o que impossibilitou a ida a campo para a realização das entrevistas. Consideramos importante expor os limites dos arranjos metodológicos de que lançamos mão. Se, para o caso das mães, a pesquisa foi feita com o emprego da etnografia e das entrevistas biográficas, para os filhos, as conversas ocorreram todas por meio virtual. Ficamos privados do entendimento de que observar não é somente ver e ouvir. Os contatos iniciais, as ligações, a recepção, o ambiente mais amplo do cenário, tudo aquilo que ganharia outras cores por meio do registro etnográfico traz as limitações de um distanciamento mediado por ferramentas computacionais. Por outro lado, incorporamos um acompanhamento mais detido das redes sociais dos nossos informantes. Sabemos hoje que parte decisiva das relações sociais são mediadas por esses dispositivos e não faz mais sentido arguir sobre uma diferenciação entre os espaços on-line e offline, como já havia mostrado Hine (2000). Para tirar partido de uma netnografia, acompanhamos as postagens e discussões presentes no Facebook como artifício para garimpar informações.

No cômputo geral, os relatos que colhemos exploram de maneira mais incisiva a dimensão política das práticas e representações dos nossos informantes, o que significa dizer que estamos operando com uma concepção de política em sentido mais amplo, que não se resume à dimensão partidária e/ou sindical (ou de engajamento em movimentos sociais), mas incorpora também aspectos da vida privada, dos comportamentos, do ordinário, que refletem posicionamentos assumidos - muito próximo de uma concepção thompsoniana de ação política que acolhe elementos dos costumes e modos de vida dos sujeitos para tratá-los por meio do recurso à noção de experiência (THOMPSON, 1981). 
Mesmo que as questões em tela neste estudo digam respeito às memórias de ex-militantes sindicais no âmbito das suas famílias e, por essa via, denotem uma concepção de política mais voltada para essa forma de engajamento, não ficamos restritos a isso. $\mathrm{Na}$ acepção que estamos trabalhando, a política se expressa igualmente nas desigualdades de gênero vivenciadas por essas mulheres (no trabalho, no sindicato e na vida privada), nos desafios da monoparentalidade (para um dos casos) e nos comportamentos assumidos na criação dos(as) filhos(as); ou seja, nas pequenas nuanças da vida cotidiana quando o pessoal é redefinido como político.

Já há farta e boa literatura expondo as incongruências, para a teoria política, sociológica e dos processos educativos, da separação entre o espaço público e o privado, produtivo e reprodutivo na análise da divisão sexual do trabalho e nas assimetrias de poder nessas esferas, como se as dinâmicas de subordinação fossem distintas (FRASER, 1990). A propósito, esse entendimento ecoa um primeiro resultado que colhemos sobre a singularidade da participação das mulheres na militância sindical e no chão de fábrica, quando afirmamos que essas trajetórias podiam ser mais bem-compreendidas ao fundir vida privada e vida pública, trabalho e casa. As formas de discriminação presentes no sindicato e nas fábricas reverberavam as desigualdades de gênero do espaço privado, na família, reforçando-as, num círculo vicioso. Portanto, não deixará de ser "político" quando os relatos tratarem de aspectos da vida ordinária.

Para compreender as formas de engajamentos políticos das mulheres que estão em análise, bem como a distensão desses vínculos no espectro geracional, com os filhos e filhas, gostaríamos de lançar mão de uma hipótese para reivindicar a possibilidade de interpretar tais engajamentos na chave das afetividades. Sucede que, como veremos a seguir, a disposição das memórias das ex-militantes sindicais no tempo presente e a apreensão delas no âmbito das famílias, com os filhos e filhas, fornecem bons indícios de que as diferenças do quadro social mais amplo em que emergem esses engajamentos mobilizam bens simbólicos emocionais distintos, o que significa que, ao fim e ao cabo, para os filhos, não é tanto o conteúdo pragmático das opções políticas que está em jogo, mas, sobretudo, a natureza dos vínculos afetivos com relação a militância e escolhas políticas dos pais. Eis a hipótese.

Se parecer legítimo arguir nessa direção, estamos propondo uma leitura que mira em dois alvos: 1) em menor medida, as estruturas socioafetivas dos contextos em que emergem esses engajamentos, no afã de compreender a dinâmica dos sentimentos políticos em disputa e, no mesmo compasso, 2) com maior ênfase, os dispositivos expressivos que se deixam entrever nos relatos e condutas. Isso posto, importa-nos analisar as diferentes maneiras como os sentimentos políticos são mobilizados nos relatos que colhemos.

Retornar à zona cinzenta das afetividades para inscrever engajamentos políticos é outro modo de dar consequência àquilo que outrora fora proscrito pelo impulso da "neutralidade afetiva" (PARSONS, 1960), ou largado no depósito das irracionalidades diante do alumbramento com a ideia de um sujeito racional, capaz de perseguir seus interesses de maneira consciente. Os efeitos se fizeram sentir nos procedimentos metodológicos, que, igualmente, almejavam neutralizar possíveis vieses na condução das pesquisas, em razão de aspectos emocionais. O distanciamento dessa perspectiva positivista acolheu, de modo distinto, a interferência dos sentimentos nos protocolos de pesquisa, de modo a assumi-los como um elemento legítimo e necessário para pensar os limites do discurso científico ${ }^{3}$, como sugere Poupart (1993).

No entanto, a pretensão de discutir os signos emocionais presentes em processos de transmissão geracional permite contribuir para a proposta teórica deste dossiê, na medida em que alcança a formação de comportamentos políticos, elegendo a família como instância educativa importante na socialização dessas memórias relacionadas às experiências de ex-militantes sindicais. Se a nossa grande inspiração é a dimensão expressiva dos sentimentos (MAUSS, 1979), para reter a ideia de que os sentimentos são sociais, não da "essência" humana, não estaremos restritos ao tipo de prática que Mauss analisou por meio de rituais 
funerários. A contrapelo, com base em uma microssociologia das relações cotidianas, interessa-nos esmiuçar os aspectos - cognitivos, ideológicos, valorativos e afetivos - da negociação dessas memórias no interior das famílias. Tendo-as já analisado no contexto do sindicato, não é de menor valor a inserção desigual das histórias dessas mulheres militantes nas disputas narrativas pela memória do ciclo de greves que ocorreu no ABC Paulista em fins da década de 1970. Há, portanto, um componente difuso, que colhemos como primeiro achado de campo e que se manifesta pelo silenciamento e pelas ausências quando comparadas a uma história conjugada, muitas vezes, no masculino, feita por homens.

Recai aqui uma sorte de dualidade emocional, que se manifesta, por um lado, pelas memórias de participação nas atividades de militância do sindicato e lutas pela melhoria das condições de trabalho e, por outro, pela evidente decepção com o reconhecimento esperado. Talvez por isso tenhamos colhido algumas recusas. Como propõe Ansart (2019), a manutenção dos sentimentos políticos requer atualização permanente de referências. O legado histórico do ciclo de greves e o tipo de sindicalismo que ali medrou, a constituição de novos sujeitos no contexto de redemocratização do país, a figura icônica de Lula para os trabalhadores, fundam "signos comoventes", na expressão de Ansart (2019).

Mesmo passados cinquenta anos daqueles acontecimentos, eles são elementos permanentemente mobilizados pela militância como exercício de dramatização dos conflitos e construção de identidades. O que estamos analisando é, portanto, a manutenção dessa memória que ambiciona “durar" (ECKERT, 2012). Há, nesse sentido, um paralelo com a discussão feita por Eckert (2012) em seu estudo com os mineiros de carvão na localidade francesa de La Grande-Combe, porque também estamos falando da perda de um universo de referências simbólicas. Isso saltará à vista na comparação com os relatos dos(as) filhos(as). Nota-se, nas memórias dessas mulheres, um sentimento de melancolia em razão das transformações na cultura de ofício dos "metalúrgicos", do fechamento de algumas empresas e das mudanças no sindicato. Como nos disse uma das nossas informantes, "isso aqui fedia a graxa".

Vejamos agora como as questões aqui suscitadas emergem nas narrativas que analisamos.

\section{Família 1 - Religião e Política}

Vilma ${ }^{4}$ nasceu no Nordeste, embora tenha migrado para São Paulo ainda criança, aos 6 anos de idade. O pai já fazia frequentes deslocamentos para trabalhar em São Paulo e, por fim, decidiu levar o resto da família, que permanecia na região de origem. Desde muito cedo, Vilma trabalhou, tendo chegado às empresas da região do ABC Paulista em meados da década de 1970. Sua trajetória ocupacional foi errática: estando mais sujeitas às frequentes demissões, as mulheres ainda enfrentavam os desafios de conciliar trabalho e vida privada. O cotidiano no chão de fábrica a motivou a engajar-se na militância sindical, em 1979, onde enfrentaria, entre outras coisas, os preconceitos associados à presença feminina nesse espaço. Foi na militância que conheceu o esposo, também metalúrgico, com quem teve três filhos e de quem, posteriormente, separou-se. Da sua trajetória, que já analisamos mais detidamente em outras ocasiões (SANTOS JUNIOR; MENEZES, 2019), queremos reter as singularidades associadas às trajetórias de mulheres no setor metalmecânico da região e às características da militância sob o peso da clivagem de gênero.

Por meio dos relatos que pudemos colher, ganha cores o que surge, na análise clássica de Abramo (1999), ao flagrar a existência de uma concepção nativa de direitos que permeia a relação entre trabalhadores e empresas, a qual será fraseada na acepção mais ampla de "dignidade", para reivindicar não uma ideia do trabalho como sacrifício redentor, mas na chave do "respeito". No universo sindical, Vilma encontrou os estigmas imputados à presença de mulheres nesse meio - suspeição de natureza moral e sexual - e as 
tensões entre a especificidade das suas demandas diante do enquadramento maior como "classe", que já fora brilhantemente catalogado por estudos como os de Souza-Lobo (2011), Humphrey (1983) e Araújo e Ferreira (1998). Em 1987, ela compôs a chapa da diretoria executiva que, entre trinta membros, tinha duas mulheres. Posteriormente, em 1992, lançou-se em uma candidatura a vereadora, mas não obteve votos suficientes para a eleição. Com essa experiência e as dificuldades enfrentadas pela demissão da empresa em que trabalhava, em 1994, decidiu romper com o Partido dos Trabalhadores (PT).

Guardemos esse breve registro biográfico de Vilma para encontrá-lo, agora, a partir das narrativas dos filhos. Importará, doravante, o diálogo com essas memórias de militância no espaço da família. Em virtude do cotidiano descompassado pelas exigências de trabalho, vida doméstica, militância sindical e partidária, Vilma teve que criar os filhos com o auxílio da mãe e/ou da sogra, sempre tentando conciliar com o trabalho. Tomaremos os relatos em conjunto, fazendo as mediações necessárias para a compreensão das trajetórias, mas sem individualizá-los em seus aspectos mais singulares, o que será feito em outro momento.

Não houve muita dificuldade para acessar os(as) filhos(as) das nossas personagens. Uma vez solicitado, ainda antes da pandemia de Covid-19, prontamente fomos colocados em contato e, com o advento da quarentena, ficamos impedidos de ir ao encontro presencial dos nossos informantes. Resolvemos recorrer, para a realização das entrevistas, à ferramenta Google Meet. Julgamos importante salientar esse aspecto por entendermos que a dinâmica do espaço virtual, não sendo a mesma do registro etnográfico in loco, impediunos de anotar elementos sempre caros em nosso argumento e que versam sobre o contexto do bairro em que vivem os entrevistados, sua casa, os acordos para a recepção e realização das entrevistas; enfim, tudo aquilo que amplia a dimensão do observar para além do mero registro visual.

Antes, porém, como maneira de subsidiar a compreensão das narrativas apresentadas na sequência, reunimos na Tabela 1, a seguir, alguns dados objetivos dos três filhos de Vilma.

Tabela 1. Perfil dos(as) filhos(as).

\begin{tabular}{cccccc}
\hline Nome & Idade & Estado civil & Filiação religiosa & Escolaridade & Profissão \\
\hline Cristiane & 32 & Casada & Neopentecostal & Superior completo & Turismóloga \\
\hline Luís & 28 & Casado & Católico & Superior completo & Comércio exterior \\
\hline Pedro & 30 & Solteiro & Neopentecostal & Superior completo & Administrador \\
\hline
\end{tabular}

Fonte: Elaboração própria.

Os filhos de Vilma não nasceram no período das greves históricas, mas ainda viveram a época em que a mãe teve passagem pela diretoria do sindicato e trabalhava nas indústrias metalúrgicas da região. As dificuldades que ela havia nos relatado sobre o fardo de ser mãe e trabalhar fora voltam a aparecer nos relatos dos filhos, que falam da "vida corrida", "vida agitada" dos pais e do cuidado com as avós. Aliás, essa dimensão do cuidado, do trabalho que se transmuta em "ajuda" (GUIMARÃES; VIEIRA, 2020), nos discursos, permanece como competência da mãe e da avó materna. É assim que, para a mais velha, Cristiane,

[...] a gente não tinha muita presença nem do meu pai nem da minha mãe, porque eles eram muito envolvidos com essas coisas de política, sindicato. Então não tinha, a gente ficava ou com a minha vó materna, que faleceu, acho que minha mãe até falou, faz pouco tempo, ou sempre com alguém que minha mãe contratava pra cuidar da gente (Cristiane, 32 anos).

O mesmo volta a aparecer na fala de Luís, 
Ah! É..., se eu não me engano, assim, acho que foi na época que minha mãe era ainda muito participativa em questão de, é..., do sindicato, da política. Então, é..., a gente acabou, foi o que eu falei, né? Acabou meio que [pausa], é..., aceitando e sabendo viver com isso, né? Assim, não que a minha mãe, ela era ausente, mas sempre foi corrido, então, ao mesmo tempo, eu sabia que a minha mãe vai chegar, minha mãe também, ao mesmo tempo, ela falava: tal hora eu chego (Luís, 28 anos).

Nos relatos dos três filhos, contudo, o foco é posto na percepção da mãe como "guerreira" e no enfrentamento conjunto, como família, das dificuldades que passaram. Embora todos tenham começado a trabalhar ainda jovens, em torno dos 16 anos de idade, havia um apelo constante da mãe para que seguissem estudando. Os filhos homens, Luis e Pedro, tiveram passagem como jovens aprendizes no Centro de Formação e Integração Social (Camp), que tinha parceria com a empresa Mercedes Benz. Os aprendizes administrativos do Camp são direcionados às áreas que a empresa necessita, não lhes restando a oportunidade de escolher em qual área trabalharão (SCHÄFFER, 2019, p. 78). Essa informação é a mais próxima que pudemos colher sobre a tentativa de dar prosseguimento à trajetória dos pais como metalúrgicos, embora não mais na produção fabril, mas em setores burocráticos. A parceria entre o Camp e a Mercedes Benz oportunizava estágios, mas apenas uma pequena parcela dos estagiários era contratada. No caso de Luís e Pedro, em virtude da não efetivação na empresa, as trajetórias ocupacionais ganharam outro destino.

\section{Ah! Tá e aí esse encaminhamento para o Camp foi, assim, por tua iniciativa mesmo?}

Então, minha mãe também [risos]. Minha mãe sempre em questão de estudo, porque meu irmão já tinha feito e eu tinha o espelho do meu irmão já tá trabalhando. Então minha mãe falava: "Oh! Luís, quando você tiver 16 anos você vai tentar o Camp também." E eu falei: "Não, tá bom, vou." Que, querendo ou não, já trabalhar cedo lá em casa nunca foi problema não, quero trabalhar por a gente ter o espelho da minha mãe, desde nova sempre trabalhou, quando tinha 14 anos já trabalhava em produção, né? (Luís, 28 anos).

Enquanto isso, o pai já havia se afastado do cotidiano do sindicato e assumido posição de distanciamento de sua trajetória de militância. Esse aspecto aparece nos relatos dos filhos como uma decisão autônoma do pai diante do que sucedeu, posteriormente, a partir da década de 2000, com o Partido dos Trabalhadores e as críticas feitas ao sindicalismo. Essa mudança emerge no relato de um dos filhos na forma de maior adesão ao grupo político que chegou ao poder nas eleições de 2018. A mãe, por sua vez, permanece engajada com a vida sindical, inclusive atuando em um dos seus setores. O simbolismo da figura do ex-operário que virou presidente do Brasil, Lula, segue exercendo grande atração em suas memórias. Não se pode dizer o mesmo para o caso do pai. Os filhos, portanto, encontrarão esse espaço cindido no que se refere ao legado das trajetórias dos pais. O clímax é atingido com o impeachment da presidente Dilma Roussef, a prisão do Lula e a eleição de Jair Bolsonaro, em 2018. Tais acontecimentos atuarão como catalisador para espevitar os significados atribuídos ao legado de militância dos pais.

Se, antes, as memórias dos pais, sobretudo da mãe, eram lidas na chave da superação, do enfrentamento das dificuldades da vida, agora, o acento no signo político desses legados assumirá, no interior da família, proeminência discursiva. Há bons motivos para crer que dois outros fatores atuaram como variáveis dependentes nesse processo, a saber: a religião e as redes sociais. Para o primeiro aspecto, religião, a filiação a uma igreja neopentecostal por parte de dois dos filhos abriu um flanco para o modo como a política se insere no contexto dessas igrejas. É sabido que, nas últimas décadas, o crescimento da 
chamada "bancada evangélica" tem sido indício da influência da religião no comportamento político dos seus fiéis, como mostram Prandi e Santos (2017). No entanto, essa também é uma característica mais difusa, que se insinua nas narrativas porque atua na chave dos comportamentos, da moralidade. Sentimos, por isso, que havia um cuidado em se esquivar dos temas mais espinhosos nas entrevistas, quando relacionávamos a maneira como os engajamentos políticos da mãe criavam zonas de atrito na relação com os filhos.

Em sua igreja, Cristiane participa, junto com o marido, de um grupo que debate assuntos da política com os demais fiéis. Conquanto tenha se mostrado sempre mais próxima da trajetória da mãe em termos políticos, não deixamos de notar de onde vem uma parcela da tensão desse diálogo intergeracional, pelo prisma da moralidade. É quando ela nos conta:

Tanto que eu acho que a bancada evangélica é, como que eu posso dizer... É que, assim, o nosso grupo político defende a família. Só que a visão de família nossa, falo nossa porque eu faço parte, então é nossa, é totalmente diferente dessa base que a minha mãe veio me ensinando, é o oposto, não bate... o Pedro é mais crítico, ele posta em rede social, eu não posto nada, ele posta em rede social a opinião dele, então o seguimento que eu sigo através da igreja é o mesmo que do meu irmão (Cristiane, 32 anos).

É digno de nota que, para Luís, o fato de Cristiane ter trabalhado em cargos comissionados na prefeitura, nas campanhas políticas da mãe, sendo a mais velha entre os irmãos, a diferencia com relação aos engajamentos políticos do irmão, Pedro, que também se converteu a uma igreja neopentecostal. Esse último, sim, ainda segundo Luís, teria ficado mais à mercê da influência da religião em suas posições políticas, manifestando-se, inclusive, a favor do governo do presidente Bolsonaro. Logo falaremos mais de Pedro. Por ora, voltemos ao segundo aspecto que mencionamos anteriormente: as redes sociais.

O uso da plataforma Facebook como arena de exposição de discussões políticas e visibilidades não deixou de afetar os membros da família em questão. É assim que Cristiane, após uma longa fala sobre como teria se afastado desse espaço para falar de política, conta que não comenta mais nenhuma publicação da mãe com esse tema, chegando mesmo a alertá-la para que não dê vazão a debates políticos por esse meio. Também Luís se mostra preocupado com a presença da mãe nessa rede social,

Ah! Não. Ela chorava, ela chorava quando o Lula foi preso. Eu ligava para ela, ela xingando [aqui ele se refere à linguagem que a mãe utilizava nas redes sociais], eu acho que foi aí que ela se aproximou mais ainda do Facebook, por que ela quis o quê? Ela quis saber quem concordava e quem discordava, então, assim, ali foi o tempo que ela se aproximou muito do Facebook. Que ela viu que ali era uma ferramenta que ela tinha para defender o ideal dela. Só que ela não entende que, tipo assim, a gente consegue interpretar, cada um interpreta do jeito que quer, é assim. A gente não pode tudo que quiser falar e pensar sair falando, postando, porque o Facebook é aberto (Luís, 28 anos).

Dos três filhos, o que mais se esquivou em fornecer detalhes sobre o seu posicionamento político foi aquele visto pelos irmãos como o que teria assumido uma posição política completamente diferente da mãe. Único que ainda reside com ela, Pedro é também o que deixa transparecer maior engajamento no fervor religioso. Todas as vezes que a conversa versava sobre política e governo, ele virava a chave para falar do "governo de Deus" e da posição divina sobre o que é política. Todas as vezes que precisou manipular categorias relativas ao comportamento político, mobilizou termos do vocabulário religioso, a denotar que suas posições só poderiam ser interpretadas como expressão de uma vontade maior, inacessível quando reduzidas ao debate político ordinário tal como ocorria na família e mesmo com os colegas do trabalho. 
Para enfrentar essa questão, teríamos que desdobrar mais amplamente os efeitos da conversão a uma igreja neopentecostal e o modo como Pedro incorporou crenças, comportamentos e modos de pensar sobre a vida, a família, a política. Esse é o limite do objeto da entrevista, uma vez que o nosso escopo era composto pelas percepções/memórias sobre a militância da mãe e as incorporações/enfrentamentos intergeracionais ${ }^{5}$.O que mais poderíamos inferir desses reposicionamentos do comportamento político diante do legado de militância dos pais?

Arriscamo-nos a dizer que a referência da trajetória de Vilma - cujas memórias são constantemente ativadas pelo seu engajamento político e pelos vínculos com a militância sindical - na relação com os filhos apenas pode ser compreendida no registro das afetividades. Dito de outro modo, o compasso das proximidades e dos afastamentos no diálogo geracional diz respeito menos ao conteúdo dos engajamentos políticos da mãe, embora haja também divergências quanto a isso, e mais à natureza dos seus vínculos afetivos. Teríamos assim, por um lado, processos de individualização e, por outro, o efeito dispersivo do pluralismo de valores nos comportamentos que ensejam negociações, rupturas e interpretações do legado dos pais. Lembremos que o espaço de socialização da família concorre com outros espaços, os quais podem apresentar configurações valorativas que colidem entre si. Alguns dados objetivos nos ajudam a mapear tais espaços. Cristiane e Luís são casados; ela e Pedro frequentam uma igreja neopentecostal; Luís é católico. Cristiane trabalha na área de saúde; Pedro e Luís trabalham no comércio. Por outro lado, o que parece estar em jogo na percepção que os filhos têm da militância dos pais diz respeito a elementos de ordem afetiva, que definem a paixão com que se reivindicam comportamentos políticos.

Há dois marcadores importantes sobre o efeito do tempo e do contexto social na ordem dos comportamentos políticos. Não à toa, Vilma sempre ressalta as conquistas auferidas pelo movimento sindical naquele momento, não apenas para a categoria dos metalúrgicos, mas igualmente para a consolidação da democracia no Brasil. O registro da memória deixa entrever essa dimensão do que é percebido hoje como "crise" e que tenta resistir, perdurar ${ }^{6}$. Os relatos dão provas dessas "estruturas socioafetivas" (LE BRETON, 2019) em que se assentam os regimes de sentido dos vínculos estabelecidos com as formas de comportamento político disponíveis.

Quando perguntado sobre as possíveis influências da história dos pais, pelo fato de também frequentar o sindicato quando jovem, Luís faz a seguinte consideração:

Muita gente fala: “Ah! Você é petista igual a sua mãe." Eu falo: "Não, pelo contrário. Eu também não apoio o PT." Minha última experiência, que eu tenho da minha mãe com política mesmo, que ela apoiou, o que ela lutou... Ah! Foi uma decepção dela. Então, assim, não tem como eu defender um ideal que eu vi que deixou a minha mãe na mão. Eu nunca fui focado em partido, eu sempre tive a visão do que é a realidade do Brasil. Infelizmente, todos têm defeitos, todos, nenhum é perfeito. [...] O que eu tenho no pensamento é esse: por mais que eles ajudam, mas eu sei que tá tirando de alguém. Então, assim, esse é meu pensamento. Minha mãe até briga às vezes, comigo, né? "Você votou em quem para presidente?" Eu falei: "Neutro, nulo." "Nulo? Você não fez isso!" [diz a mãe]. "Fiz, mãe, eu não acredito que a senhora vai falar, mãe. Desculpa, mas é, eu não concordo. Quem é que tem de opção?” Teve uma outra [eleição] que teve o primeiro turno, nessa eleição eu votei no Amoedo. Minha mãe queria me deserdar [risos].

Mas os seus irmãos pensam assim?

Ah, não! Minha irmã, ela é mais velha, então ela conviveu e ela trabalhou um tempo na prefeitura. Então, ela também era muito ligada com a política. Ela conviveu com pessoas da política e tal. Então ela tem um pouco do lado da minha mãe. Meu irmão não [referindo-se a Pedro]. Meu irmão tá igual meu pai, tá radical [risos] (Luís, 28 anos). 
A figura do pai sempre aparece nos relatos dos filhos como aquele que se "distanciou", como uma ação autônoma; uma figura a quem se pode atribuir algum ressentimento no saldo do legado de militância. Contudo, na narrativa de Vilma, a mesma cena surge como "esquecimento" dos demais companheiros. Aqui, quem age é a instituição, afastando pessoas. Nessa acepção, o pai teria sido vítima. Pensamos que um e outro não se excluem. A atitude de distanciamento se assemelha, também, a um mecanismo de proteção, como se existisse para driblar a crise. O que não é dito, não é verbalizado, seria também um gradiente das percepções e atitudes relacionadas aos sentimentos políticos, revelando-se como silêncio e/ou resignação. Esta será, a propósito, a brecha que nos conduz à próxima família.

\section{Família 2 - Monoparentalidade e Militância}

A segunda família que elegemos para análise tem, na figura de Regina, 73 anos, a trajetória de uma migrante nordestina que deixa o sertão baiano e chega ao ABC Paulista, levada por um irmão, para trabalhar nas indústrias da região. Da família de pequenos produtores rurais, a primeira a migrar foi uma irmã mais velha, após o casamento, em 1966, seguida por dois irmãos. Regina chega posteriormente, em 1972, com 23 anos, atraída, como ela nos conta, pelas histórias desses irmãos. Moravam em São Bernardo do Campo. Os irmãos homens logo se inseriram nas indústrias metalúrgicas. Já Regina, tendo trabalhado em outras ocupações nos primeiros anos após sua chegada, encontrou emprego no mesmo setor de atividade econômica. Todavia, eis que lhe ocorre uma gravidez inesperada nessas primeiras experiências de emprego e os efeitos sobre a sua trajetória serão decisivos.

Ocupando os trabalhos mais precários e, portanto, sujeitas a maior rotatividade (GUIMARÃES; BRITO; BARONE, 2016), Regina teve o primeiro filho quando estava desempregada. Nesse momento de dificuldade, ao assumir a criação do filho sem a presença do pai da criança, ela nos conta que os irmãos a acolheram e permitiram que ela residisse com eles. No retorno ao trabalho, tentou de várias maneiras esconder a existência do filho para evitar que a empresa a demitisse pelas dificuldades de conciliação com as demandas de sua criação, chegando a enviá-lo para a casa dos pais, na Bahia. Aqui, surgem, na narrativa, os elementos que servem de substrato para a expressão de sentimentos que, na forma nativa, são percebidos como "indignação", seja em razão do preconceito por ser "mãe solteira”, seja pelas opressões no chão de fábrica, que atingiam ainda mais as mulheres trabalhadoras. Transparece, em seu relato, o modo como a exploração do trabalho era vivenciada no cotidiano. É por conta disso, inclusive, que ela é levada ao sindicato.

Sucede que o irmão, que já frequentava as assembleias e havia participado de algumas greves, decide levá-la para dirimir uma dúvida sobre um acordo que ela fez com a empresa ao ser demitida. Perante as constantes faltas para cuidar da saúde do filho, a empresa a obrigara a assinar uma carta em que ela pedia a demissão e abria mão dos seus direitos. Uma vez lá, ao frequentar as assembleias, ela percebe que havia outras mulheres que enfrentavam as mesmas dificuldades. O sofrimento, vivido como experiência individual, assumia, com o compartilhamento de experiências das outras trabalhadores, a dimensão de uma reivindicação que poderia ser coletiva. Nesse sentindo, conta-nos ela:

Quando eu comecei a ir nas assembleias, aí eu via que tinha as mulheres, comecei a me entrosar, e era uma coisa. Parece, era isso que eu te falo, o mundo se restringia a mim e a meu filho. E aí, quando eu comecei no sindicato, eu comecei a perceber que não, que não era assim, que a minha história não era só minha. Descobri outras mulheres, mães solteiras, inclusive, nessa caminhada. A Helena é uma delas, dessa época; a Rosinha e assim outras que eu fui conhecendo 
e que têm a mesma história que eu. Porque eu me sentia tão retraída que eu achava que eu era a única. Que eu estava assim, fora do mundo (Regina, 73 anos).

A partir daí, se acompanharmos sua trajetória, Regina se engajará na militância sindical até vir a ocupar, posteriormente, cargos na diretoria e na Central Única dos Trabalhadores (CUT). Contudo, o que nos interessa com essa breve apresentação é reter a maneira como essas memórias são narradas. Como no caso anterior, é-nos útil a distinção que Rosenthal (2014) estabelece entre história de vida vivenciada e história de vida narrada. É nessa última acepção que estamos pondo o foco dessa análise, por entender que é sobre ela que se debruça uma pretensão de apresentação de si, no sentido de uma autorrepresentação biográfica. Essa diferença de temporalidades, queremos crer, é o que nos permite circunscrever analiticamente o que constitui um legado no processo de transmissão geracional. Vejamos mais de perto.

Assim como em outros casos que analisamos (SANTOS JUNIOR; MENEZES, 2019), vimos que o ato de recordar e narrar essas memórias era percebido como um drama para Regina. O distanciamento da militância e o que é entendido como a destruição de um universo de referências simbólicas dos tempos de luta $^{7}$ sugerem as ambivalências do lugar que esses sentimentos políticos ocupam em sua vida atualmente, $o$ que não tem como corolário a resignação - haverá resistências. É por meio do relato dos filhos que avançamos na compreensão dessa dimensão dialógica das memórias, que querem, como dissemos, durar no tempo. Reunimos, na Tabela 2, como no exemplo anterior, um apanhado com alguns dados do filho de Regina.

Tabela 2. Perfil do filho de Regina.

\begin{tabular}{cccccc}
\hline Nome & Idade & Estado civil & Filiação religiosa & Escolaridade & Profissão \\
\hline Zito & 47 & Casado & $\begin{array}{c}\text { Católico } \\
(\text { diz frequentar o espiritismo })\end{array}$ & Superior completo & Advogado \\
\hline
\end{tabular}

Fonte: Elaboração própria.

O único filho de Regina tem hoje 47 anos e está no segundo casamento, tendo já um filho com a primeira esposa. Dele, conhecíamos apenas as dificuldades que ela nos contou quando da gravidez e do nascimento. Zito traz boas lembranças dos tempos em que viveu com os avós no sertão da Bahia e do carinho dos tios que estavam em São Paulo para acolhê-lo, já maior, em seu retorno. Ciente de que a nossa conversa abordaria as memórias da mãe, não hesita em dizer que a militância acarretou sequelas ainda vivas nos dias de hoje. Todavia, as recordações também falam das peripécias da mãe para criá-lo e do que ele vê como "amadurecimento" em sua vida, quando teve que trabalhar ainda adolescente para ajudar em casa. A trajetória da mãe aparece, no relato de Zito, dividida em três fases, todas elas tipificadas no registro dos afetos. O primeiro é o da mãe "aguerrida", que assume a tarefa de ser o pai e a mãe ao mesmo tempo. O segundo é o da mãe "agressiva", capaz de enfrentar qualquer um que ousasse desafiá-la em questões ligadas ao trabalho.

Todas as pessoas que veem hoje a minha mãe, por exemplo, você conheceu a minha mãe muito mais terna, muito mais tranquila, muito mais doce. Essas pessoas [referindo-se a antigos militantes], quando você fala com elas, elas têm uma visão muito mais agressiva, porque ela se tornou agressiva, eu vi a minha mãe bater em homem, minha mãe não leva desaforo para casa (Zito, 47 anos).

Por fim, temos a imagem da mãe que está depressiva, triste. Este último aspecto, porém, insinua-se de maneira muito difusa na sua fala. Sabemos, por conta dos vários encontros que tivemos com Regina, que 
a densidade da narrativa de Zito é posta para realçar a sua militância, que teria começado no movimento estudantil, na escola, desdobrando-se no contexto do trabalho como metalúrgico, pois a mãe o havia apresentado à política sindical e partidária desde muito cedo.

Você também nos contou do grupo de teatro. Esse grupo de teatro é aquele Forja ${ }^{8}$ lá do sindicato do $A B C$ ?

Isso, é o grupo de teatro Forja. Aquele momento, ele foi muito rico. É..., não dá para explicar. Eu acho que vocês já ouviram muito, então, assim, os operários ali tiveram, foram apresentados a coisas que a gente nunca viu. A gente foi apresentado a música popular brasileira, a gente foi apresentado a teatro, a coisas que a gente nunca tinha visto. E eu era moleque. Eu ia com a minha mãe. Então, para mim, era uma coisa, assim, muito legal

Ela te levava, então, no sindicato?

Levava, levava o tempo todo [risos].

Mas você já tinha se engajado nessa coisa do movimento estudantil? Nesse momento aí?

Não. No início, ela me levava muito por conta [de] não ter que pagar alguém para olhar: "vou levar, melhor ele ir comigo do que ele ficar aî" [dizia a mãe]. A maioria das vezes, a gente morava em periferia. Então, eu fui muito (Zito, 47 anos).

Depreende-se, direta ou indiretamente, que o sindicato constituía um espaço de socialização, de referência na vida dos(as) trabalhadores(as) - elementos que darão forma à cultura de ofício que medrou nessa região (FRENCH, 1995).

Zito nos conta que a decisão de cursar Direito em uma faculdade privada chega, a propósito, por conta de uma demissão por motivo de greve na Pirelli. Nosso personagem vai, assim, contaminando sua história vivenciada com o sentido de militância da trajetória da mãe, como que para prolongar os efeitos sobre a sua memória. No entanto, se é razoável supor, como diz Ansart (2019), que os sentimentos políticos se gastam pela repetição, é o aspecto da crise do legado o mais revelador dos impasses nos processos de transmissão das afetividades políticas. É o momento em que Zito volta a falar do modo como ele entende a trajetória da mãe.

Ela tem uns altos e baixos na questão emocional. Eu também sofri junto com ela, porque, na verdade, a gente que tava dentro dessa coisa. Por exemplo, no final do meu primeiro relacionamento, do meu primeiro casamento, eu tentei me separar uma vez e ela, nossa, que não deixava, que uma coisa assim absurda [se acontecesse]. Eu sempre trouxe muito ela, porque sou filho único e essa coisa toda, dessa trajetória que vocês ouviram dela, então, eu sempre tentei incluir ela na minha vida particular, principalmente nos meus relacionamentos [...]. Nossa, quantas vezes a gente tentou incluir ela e ela chorava. Então ela tem altos e baixos mesmo. Então hoje, graças a Deus, com todas as dificuldades, a minha mulher e eu, a gente tem muito esse zelo por ela. [...] Então, essa coisa que ela tem é um efeito colateral do movimento sindical. Ela teve um efeito colateral de toda essa trajetória maluca. Você vê, essa coisa de você ver também 
tudo o que você lutou agora tendo retrocesso, principalmente na questão trabalhista. Ela tem uma visão muito ampla nas questões, principalmente saúde do trabalhador. Se tá havendo um retrocesso muito grande, parece uma derrota, né? Parece que tudo que você defendeu uma vida inteira para chegar aqui e agora você vê voltar, então ela... É difícil de lidar com esses altos e baixos. Que hoje, nesse momento, ela já tá bem melhor, ela melhorou muito (Zito, 47 anos).

Como no caso anterior, parece haver uma dualidade emocional na narração desses engajamentos políticos no interior das famílias: os membros da segunda geração se expressam ora realçando o tom épico da história vivenciada na militância, ora aproximam-se do trauma de um longo investimento afetivo que está em risco de perecer.

Quando provocamos Zito sobre como se desdobram, no interior da sua família e na relação com os filhos, essas histórias, eis o que ele nos descreve:

Ah! Todos têm uma certa visão mais crítica. Hoje, eu saí um pouco dessa questão da política partidária, sabe? De tanto tá dentro da política partidária, às vezes, te tampa um pouco a visão do mundo. Engraçado, né? Ao mesmo tempo que abre para algumas coisas, dá uma fechada. Não é igual à política sindical. A política sindical é mais plural. A política partidária às vezes você mata uma opinião sua por conta de conciliar com aquela coisa (Zito, 47 anos).

Se tomarmos, como propõe Ansart (2019), o sindicato não meramente como expressão da organização coletiva dos trabalhadores - instituição burocrática, que operacionaliza os interesses de uma classe -, mas como aparelho afetivo, é possível compreender os modos pelos quais ele fomentou um sentimento de pertença, que agregava pessoas, fosse pelas condições de uma modalidade de trabalho constantemente vilipendiada, fosse pelo viés do acolhimento, da compensação para aqueles que, como as nossas personagens, mulheres metalúrgicas, enfrentavam sentimento de perda, de desamparo. Isso significa que, retornando a Mauss (1979), estamos interpretando as expressões de emoções e sentimentos políticos de ex-militantes e de seus filhos e suas filhas, como parte das regras sociais - distantes, pois, do lugar que eles ocupam no seio de abordagens teóricas mais afeitas à racionalidade do agir. As relações familiares em tela neste estudo funcionam como indutor de um saber afetivo difuso dos vínculos e engajamentos políticos dos pais, vistos aqui pela janela da memória, os quais podem afetar suas histórias pessoais. Lançada a proposta, vejamos agora como podemos avançar nessa agenda de pesquisa.

\section{A Dramatização dos Conflitos}

O desafio a que nos lançamos não é apenas prospectivo, de garimpar novos achados no afã de pavimentar o argumento de ser possível inscrever os engajamentos, conflitos e heranças de trajetórias de militantes sindicais - mas não somente elas - no registro dos afetos políticos. É nessa "zona cinzenta”, que beira o ininteligível, que encontramos, por meio das memórias, as ambiguidades dos vínculos forjados por uma forma de engajamento político que canalizou o que fora percebido como injustiça no espaço do trabalho, da casa, ou mesmo do sindicato, para traduzir a visão de um mundo que talvez fosse possível. Não foi por um tropeço que deparamos, durante a pesquisa, com as disputas narrativas que se dão em torno de quem poderá contar e o que poderá ser contado do ciclo de greves históricas do ABC Paulista. Seguramente, todos são elegíveis para fazê-lo, mas é nesse mercado de versões que encontramos os cenários emocionais em que se assentam as trajetórias de vida dos casos que analisamos nesse texto. 
Tínhamos, a princípio, os relatos das mulheres ex-metalúrgicas e com passagem pela militância sindical. Os silenciamentos de outrora, que ainda reverberavam nessas disputas narrativas, ecoavam também nas famílias? Sim, essa é a nossa unidade social mínima e é por meio dela, da análise da mulher e do seu lugar dentro das famílias, da participação tanto nos momentos de greve como durante o período de militância sindical, que encontramos as memórias narradas nesse ambiente. Agora, como vimos, são os filhos e filhas que acolhem e/ou rejeitam o legado que está sendo transmitido, não apenas como substância de um aprendizado manifesto, mas, sobretudo, como a transmissão de valores e éticas, códigos de comportamentos (ELIAS, 1994) latentes, que derivam do conteúdo vivido por essas famílias.

Os filhos oferecem a possibilidade do diálogo geracional dessas memórias, assumindo-as, porém, com algum distanciamento crítico. É nesse momento que, conquanto reconheçam e deem provas do esforço dessas mães para conciliar trabalho e vida - no termo êmico "guerreiras" -, também se permitem reinterpretar, em outra chave, a natureza desses engajamentos políticos. Para dizer de modo simples, é como se dissessem: "Sim, concordo com as opções políticas ofertadas, mas, talvez não com a intensidade afetiva anteriormente depositada nesses vínculos." Isso desvela a possibilidade de mais investimentos de pesquisa para compreender, por exemplo, se os investimentos afetivos (dos e das militantes, assim como de seus filhos) diferem conforme o gênero.

Aquilo que, nos relatos dessas famílias, insinua-se como uma sorte de ressentimento, do que é tema "delicado" para tratar em família, como quando o assunto é política, revela, sob o peso da história narrada, o lugar dos afetos. É como sugere Ansart (2004):

A dificuldade é redobrada quando se trata não somente de analisar os ódios, mas de compreender e explicar aquilo que precisamente não é dito, não é proclamado; aquilo que é negado e que se constitui, entretanto, como um móbil das atitudes, concepções e percepções sociais. O objetivo esquiva-se; é preciso formular a hipótese de sua importância e reconstituir o invisível que, se não é totalmente inconsciente, ao menos em parte é não consciente. É preciso formular a hipótese do papel do inconsciente na política, hipótese audaciosa em seu princípio e em suas realizações (ANSART, 2004, p. 29).

Os argumentos aqui lançados ainda carregam os vestígios de uma proposição work in progress, mas julgamos que o acúmulo dos achados, alguns já publicados, permite-nos colher as críticas que o debate venha a suscitar.

\section{Contribuições dos Autores}

Problematização e Conceitualização, Santos Junior J e Menezes MA; Metodologia,Santos Junior J e Menezes MAJ; Análise, Santos Junior J e Menezes MA; Redação, Santos Junior J e Menezes MA.

\section{Notas}

1. Trata-se do projeto Movimentos Cruzados e Histórias Específicas de Operários e Trabalhadores Rurais. Análise Comparativa dos Ciclos de Greves Iniciados pelos Metalúrgicos de São Paulo e do ABC Paulista e pelos Canavieiros de Pernambuco no Final dos Anos 70. O projeto teve financiamento da CAPES, edital n. 12/2015, e foi coordenado pelo Prof. Dr. José Sérgio Leite Lopes (UFRJ/Museu Nacional). 
2. Não há motivos para crer que as narrativas dos(as) filhos(as) apenas sejam relevantes quando se trata da militância das mães, recorte proposto na pesquisa. Contudo, temos indícios de que a vida privada afeta de maneiras diferentes a militância de homens e de mulheres, como expusemos em outro momento (SANTOS JUNIOR; MENEZES, 2019).

3. Não se faz afirmação como essa impunemente. Enfrentá-la nos limites desse texto imporia uma longa digressão, o que extrapola os objetivos aqui propostos. Para um encaminhamento do atual cenário nessa temática, ver, por exemplo, Clough (1992).

4. Os nomes doravante citados são fictícios, bem como houve consentimento para participar da pesquisa, respeitando os princípios éticos recomendados.

5. Essa brecha reclama um investimento analítico com o foco mais direto na conversão e em suas consequências na trajetória de Pedro, qual seja: em que momento da vida ocorreu? Quem eram as pessoas de suas redes, suas práticas e seus modos de compreensão da religião?

6. O que nos remete ao que colhemos em campo no sindicato e que se traduz na intensa disputa narrativa sobre $a$ quem compete contar a memória das greves e o que pode ser contado (SANTOS JUNIOR; MENEZES, 2019).

7. A prisão de Lula, em abril de 2018, a eleição de Jair Bolsonaro, em novembro do mesmo ano, as mudanças no sindicalismo e o fechamento de montadoras na região do ABC Paulista, para citar alguns exemplos.

8. O Forja foi um grupo de teatro que teve existência entre 1979 e 1991, formado por dirigentes sindicais e trabalhadores da base, que tinha como diretor Tim Urbinatti. Na entrevista, ele nos contou que houve um refluxo do movimento após as greves de 1978 e, com a intervenção no sindicato, o grupo foi para as ruas para seguir com o trabalho de comunicar aos trabalhadores o que a diretoria planejava como estratégia de ação. A ideia era traduzir, usando a linguagem teatral, o que estava em pauta no sindicato, valendo-se, sobretudo, dos próprios trabalhadores como atores. Ver também Urbinatti (2011).

\section{Referências}

ABRAMO, L. W. O resgate da dignidade: greve metalúrgica e subjetividade operária. Campinas: Editora da Unicamp/São Paulo: Imprensa Oficial, 1999.

ANSART, P. História e memória dos ressentimentos. In: BRESCIANI, S.; NAXARA, M. (orgs.). Memória e (res)sentimento: indagações sobre uma questão sensível. Campinas: Editora da Unicamp, 2004.

ANSART, P. A gestão das paixões políticas. Curitiba: Ed. UFPR, 2019.

ARAÚJO, A. M. C.; FERREIRA, V. C. Construindo um espaço: a participação das mulheres no movimento sindical (1978-1988). Revista de Sociologia e Política, Curitiba, v. 10, n. 11, p. 55-81, 1998.

BOURDIEU, P. A ilusão biográfica. In: FERREIRA, M. M.; AMADO, J. (orgs.). Usos \& abusos da história oral. Rio de Janeiro: Editora FGV, 2006.

CLOULGH, P. T. The end(s) of etnography: from realism to social criticism. Newbury Park/California: SAGE Publications, 1992.

ECKERT, C. Memória e trabalho: etnografia da duração de uma comunidade de mineiros do carvão (La Grand-Combe, França). Curitiba: Appris, 2012. 
ELIAS, N. O processo civilizador. Rio de Janeiro: Jorge Zahar, 1994.

FRASER, N. Rethinking the public sphere: contribution to the critique of actually existing democracy. Social Text, n. 25-26, p. 56-80, 1990. https://doi.org/10.2307/466240

FRENCH, J. D. O ABC dos operários. Conflitos e alianças de classe em São Paulo. São Paulo: Hucitec, 1995.

GUIMARAES, N. A.; VIEIRA, P. P. F. As “ajudas”: o cuidado que não diz seu nome. Estudos Avançados, São Paulo, v. 34, n. 98, p. 7-24, 2020. https://doi.org/10.1590/s0103-4014.2020.3498.002

GUIMARÃES, N. A.; BRITO, M. M. A.; BARONE, L. S. Mercantilização no feminino: a visibilidade do trabalho das mulheres no Brasil. Revista Brasileira de Ciências Sociais, São Paulo, v. 31, n. 90, p. 17-38, 2016. https:// doi.org/10.17666/319017-38/2016

HALBWACHS, M. A memória coletiva. São Paulo: Centauro, 2013.

HINE, C. Virtual ethnography. London: SAGE Publications, 2000.

HUMPHREY, J. Sindicato: um mundo masculino. Novos Estudos CEBRAP, v. 2, n. 1, São Paulo, p. 47-52, 1983.

LE BRETON, D. Antropologia das emoções. Petrópolis: Vozes, 2019.

MAUSS, M. A expressão obrigatória dos sentimentos. In: OLIVEIRA, R. C. (org.). Mauss - antropologia. São Paulo: Ática, 1979. (Coleção Grandes Cientistas Sociais v. 11.)

MÉDA, D. Le travail, une valeur en voie de disparition? Paris: Flammarion, 2010.

PARSONS, T. Structure and process in modern societies. New York: Free Press, 1960.

POUPART, J. Discours et débats autour de la scientificité des entretiens de recherche. Sociologie et Sociétés, Montréal, v. 25, n. 2, p. 93-110, 1993.

PRANDI, R.; SANTOS, R. W. Quem tem medo da bancada evangélica? Posições sobre moralidade e política no eleitorado brasileiro, no Congresso Nacional e na Frente Parlamentar Evangélica. Tempo Social, São Paulo, v. 29, n. 2, p. 187-214, 2017. https://doi.org/10.11606/0103-2070.ts.2017.110052

RICOEUR, P. O si-mesmo como um outro. Campinas: Papirus, 1991.

ROSENTHAL, G. História de vida vivenciada ehistória de vida narrada: A interrelação entreexperiência, recordar e narrar. Civitas, Porto Alegre, v. 14, n. 2, p. 227-249, 2014. https://doi.org/10.15448/1984-7289.2014.2.17116

SANTOS JUNIOR, J.; MENEZES, M. A. À margem da história? Mulheres metalúrgicas e a memória das greves do ABC (1978-1983). In: LEITE LOPES, J. S.; HEREDIA, B. A. (orgs.). Movimentos cruzados, histórias específicas. Rio de Janeiro: Editora UFRJ, 2019. p. 227-266.

SANTOS JUNIOR, J.; THIBES, M. Z.; MENEZES, M. A. Disjunções e ambivalências: famílias migrantes nordestinas no ABC paulista. Civitas, Porto Alegre, v. 19, n. 3, p. 675-691, 2019. https://doi. org/10.15448/1984-7289.2019.3.28647

SCHÄFFER, S. R. Etnografia das relações de trabalho de aprendizes-trabalhadores e seus supervisores: política pública de aprendizagem, inserção, formação profissional e acidentes. 2019. Texto de qualificação 
(Doutorado em ciências Humanas e Sociais) - Programa de Pós-graduação em Ciências Humanas e Sociais, Universidade Federal do ABC, 2019. Mimeo.

SOUZA-LOBO, E. A classe operária tem dois sexos: trabalho, dominação e resistência. 2. ed. São Paulo: Perseu Abramo, 2011.

THOMPSON, E. P. A miséria da teoria ou um planetário de erros: uma crítica ao pensamento de Althusser. Rio de Janeiro: Jorge Zahar, 1981.

URBINATTI, T. Peões em cena: Grupo de Teatro Forja. São Paulo: Hucitec, 2011.

VELHO, G. A busca da coerência: coexistência e contradições entre códigos em camadas médias urbanas. In: FIGUEIRA, S. A. (org.). Cultura da psicanálise. São Paulo: Brasiliense, 1985. p. 169-178.

\section{Sobre os Autores}

Jaime Santos Junior é Doutor em Sociologia pela Faculdade de Filosofia Letras e Ciências Humanas da Universidade de São Paulo (FFLCH/USP). Possui experiência nas áreas de Sociologia e Antropologia do Trabalho Rural, com especial destaque para os seguintes temas: Trabalho, Sindicalismo, Migrações, Famílias, Dominação e Resistência, Memórias, Culturas operárias e Identidades.

Marilda Aparecida de Menezes é PhD pela University of Manchester. Possui experiência nas áreas de Sociologia e Antropologia, com ênfase em Sociologia e Antropologia Rural e Urbana, atuando, principalmente, nos seguintes temas: Migrações internas e internacionais; Família; Gênero e gerações; Memória e identidades; Metodologia da história oral; Migrações e redes sociais; Trabalhadores em usinas de cana de açúcar; Dominação e resistência; Movimentos sociais agrários.

Recebido: 10 jul. 2020

Aceito: 25 ago. 2020 